\title{
Prenatalnie zdiagnozowana złożona wrodzona wada serca z zespołem Cri du chat i wieloma przeciwwskazaniami do leczenia kardiochirurgicznego - opis przypadku
}

\author{
Prenatal diagnosis of Cri du chat, complicated with complex heart defect \\ with many contraindications to cardiac surgery - a case report
}

\author{
Katarzyna Leszczyńska ${ }^{1}$, Maciej Chojnicki ${ }^{2}$, Katarzyna Stefańska ${ }^{1}$, Krzysztof Preis $^{1}$, \\ Katarzyna Gierat-Haponiuk ${ }^{3}$, Ireneusz Haponiuk ${ }^{2,4}$ \\ ${ }^{1}$ Klinika Położnictwa i Ginekologii Gdańskiego Uniwersytetu Medycznego \\ ${ }^{2}$ Oddział Kardiochirurgii Dziecięcej Szpitala im. św. Wojciecha w Gdańsku-Zaspie \\ ${ }^{3}$ Klinika Rehabilitacji Gdańskiego Uniwersytetu Medycznego \\ ${ }^{4}$ Katedra Fizjoterapii Wydziału Rehabilitacji i Kinezjologii Akademii Wychowania Fizycznego i Sportu \\ im. Jędrzeja Śniadeckiego w Gdańsku
}

\section{Streszczenie}

Przedstawiono przypadek prenatalnie rozpoznanego zespołu Cri du chat, powikłanego złożoną wrodzoną wadą serca, z wieloma problemami dodatkowymi, które ostatecznie stały się podstawą do dyskwalifikacji dziecka ze złożonego leczenia kardiochirurgicznego. Ze względu na występowanie złożonej morfologii wrodzonej wady serca, z potencjalną koniecznością wieloetapowego leczenia, ciężką postać zespołu genetycznego potwierdzonego w szczegółowych badaniach cytogenetycznych, ciężki przebieg kliniczny oraz liczne przeciwwskazania związane z dysfunkcją wielu narządów, dziecka ostatecznie nie zakwalifikowano do leczenia kardiochirurgicznego.

Posiadanie wiedzy opartej na diagnostyce prenatalnej pozwala wstępnie przewidzieć ciężkie konsekwencje u noworodka oraz objęcie kompleksową opieką paliatywną dziecka i jego rodziny.

Szczegółowe poradnictwo genetyczne umożliwia przygotowanie rodziców na urodzenie dziecka z wadą genetyczną i złożoną wrodzoną wadą serca niekwalifikującą się do leczenia kardiochirurgicznego.

Słowa kluczowe: diagnostyka prenatalna, echokardiografia płodowa, zespół Cri du chat, wrodzone wady serca, opieka perinatalna

Folia Cardiologica 2017; 12, 5: 523-527

\section{Wstęp}

Zespoły genetyczne często towarzyszą wrodzonym wadom serca, które można coraz skuteczniej diagnozować w okresie życia płodowego. Złożoność wielu problemów towarzyszących wrodzonej wadzie serca może być podstawą do dyskwalifikacji z kompleksowego leczenia kardiochirurgicznego. Od współczesnej diagnostyki prenatalnej oczekuje się efektywności, która może zapewnić precyzyjne rozpoznanie zarówno wrodzonej wady serca, jak i wad towarzyszących oraz potencjalnych problemów, wskazujących na niekorzystne rokowanie u noworodka. 
W pracy przedstawiono przypadek prenatalnie rozpoznanego zespołu Cri du chat, powikłanego złożoną wadą serca, z wieloma problemami dodatkowymi, które ostatecznie stały się podstawą do dyskwalifikacji dziecka ze złożonego leczenia kardiochirurgicznego. Na uwage zasługuje zweryfikowane po urodzeniu prenatalne rozpoznanie zespołu mnogich wad wrodzonych u płodu, na podstawie których możliwe było określenie przyszłych przeciwwskazań do leczenia operacyjnego noworodka już w okresie wczesnych badań płodowych.

\section{Założenia}

Zespół Cri du chat opisali w 1963 roku Lejeune i wsp. Na tak zdefiniowany zespół składają się liczne wady wrodzone, upośledzenie umysłowe, małogłowie, nieprawidłowości w obrębie twarzy oraz miauczący płacz u niemowląt z delecją chromosomu z grupy B, później zidentyfikowany jako 5p-. Zespół Cri du chat jest wywołany częściową delecją w obrębie krótkiego ramienia chromosomu 5. Większość przypadków (80-85\%) występuje sporadycznie i jest spowodowanych delecją de novo $5 p(15.3 \rightarrow 15.2)$. Przyczyną 10-15\% przypadków jest nieprawidłowa segregacja zrównoważonej translokacji rodzicielskiej (ojcowskiej lub matczynej), w której monosomii $5 p$ często towarzyszy częściowa trisomia partnerskiego chromosomu zaangażowanego w translokację rodzicielską. Fenotypy takich chorych mogą się wiązać z cięższym obrazem klinicznym niż fenotypy z izolowaną monosomią $5 p$. Jest to spowodowane udziałem dodatkowego niezrównoważenia kariotypu przez trisomiczną część genomu.

W większości przypadków stwierdza się delecje terminalne z utratą 30-60\% materiału genetycznego 5p. U mniej niż 10\% noworodków występują inne rzadkie aberracje cytogenetyczne (delecje interstycjalne, mozaiki, chromosomy pierścieniowe oraz translokacje de novo). Utrata małego regionu 5p15.2 (region krytyczny dla zespołu Cri du chat) jest skorelowana z wystąpieniem wszystkich objawów klinicznych zespołu, z wyjątkiem „kociego płaczu”, który mapuje się do regionu 5p15.3 (region krytyczny „kociego płaczu”). Wyniki badań sugerują istnienie dwóch nieciągłych regionów krytycznych zawierających geny odpowiedzialne za etiologię choroby.

W około $80 \%$ ulegający delecji chromosom 5 de novo jest pochodzenia ojcowskiego.

\section{Objawy kliniczne zespołu Cri du chat}

U noworodków z Cri du chat występuje charakterystyczny miauczący płacz - jest to dźwięk o wysokiej częstotliwości, monochromatyczny, uważany za patognomoniczny dla tego zespołu. Do charakterystycznych objawów należą ponadto: niska masa ciała po urodzeniu, hipotonia mięśniowa, małogłowie, opóźnienie wzrastania, okrągła twarz z pełnymi policzkami, hiperteloryzm, zmarszczki nakątne, skierowane w dół szpary powiekowe, zez, płaska nasada nosa, skierowane ku dołowi kąciki ust, małożuchwie, nisko osadzone małżowiny uszne, krótkie palce, pojedyncza bruzda dłoniowa, wady serca (ubytek w przegrodzie międzykomorowej [VSD, ventricular septal defect], ubytek przegrody przedsionkowej [ASD, atrial septal defect], przetrwały przewód tętniczy Botalla [PDA, persistent ductus arteriosus], tetralogia Fallota [TOF, tetralogy of Fallot]).

Do rzadziej stwierdzanych objawów należą rozszczepienie wargi i podniebienia, przeduszne przetoki i wyrostki skórne, dysplazja grasicy, nieprawidłowy zwrot jelita, jelito olbrzymie, przepuklina pachwinowa, obustronne zwichnięcie stawu biodrowego, wnętrostwo, spodziectwo, rzadkie malformacje nerkowe (nerka podkowiasta, nerka ektopowa lub agenezja nerek, wodonercze), klinodaktylia $\mathrm{V}$ palca u rąk, stopa końsko-szpotawa, płaskostopie, syndaktylia II i III palca u rąk i u stóp, oligosyndaktylia oraz nadmierna ruchomość w stawach [1, 2]. Z kolei typowo obserwowane powikłania okresu noworodkowego to słaby odruch ssania, konieczność zastosowania terapii w środowisku inkubatora, zespół błon szklistych, żółtaczka i odwodnienie.

\section{Opis przypadku}

Pacjentka w wieku 34 lat, w 4. ciąży, w 34. tygodniu ciąży (tc.), została przyjęta na oddział patologii ciąży z powodu stwierdzonej w badaniu ultrasonograficznym (USG) hipotrofii płodu. W wywiadzie pacjentka przebyła dwa wcześniejsze poronienia oraz jeden poród zdrowej dziewczynki, urodzonej o czasie.

W wykonanym badaniu USG potwierdzono zahamowanie wewnątrzmacicznego wzrostu płodu (IUGR, intrauterine growth restriction) z opóźnieniem o około 4 tygodnie w stosunku do wieku ciążowego oraz dodatkowo zaobserwowano wentrikulomegalię i złożoną wadę serca płodu pod postacią podwójnego odejścia wielkich naczyń z prawej komory (DORV, double outlet right ventricle), przełożenia wielkich naczyń (TGA, transposition of great artery) oraz VSD.

Diagnostyke prenatalną rozszerzono o konsultację kardiologa dziecięcego, który potwierdził rozpoznanie na podstawie badania metodą echokardiografii płodowej. Pacjentce pobrano krew na badanie w kierunku TORCH (toxoplasmosis, other, rubella, cytomegalovirus and herpes), tj. zespołu fetopatii, a ze względu na IUGR i wielowadzie zaproponowano badanie kariotypu płodu za pomocą pobrania krwi płodu z żyły pępowinowej drogą kordocentezy. W wynikach badań w kierunku TORCH stwierdzono jedynie dodatnie przeciwciała w klasie IgG przeciwko różyczce, na którą pacjentka wcześniej chorowała. Pozostałe wyniki badań laboratoryjnych - w tym morfologia krwi żylnej, badanie ogólne moczu i badanie hormonów tarczycowych - nie odbiegały od normy. 
Po 10 dniach od kordocentezy uzyskano wynik kariotypu płodu: 45, XX, der(5)t(5;21)(p13;q11.2),-21. W komentarzu diagnostycznym stwierdzono występowanie niezrównoważonej translokacji między chromosomami 5 i 21, prowadzącej do częściowej monosomii ramion krótkich chromosomu 5 i ramion długich chromosomu 21. Pacjentka otrzymała szczegółową opinię genetyczną, w której określono, że obecność niezrównoważonej translokacji u płodu, szczególnie częściowa utrata ramion krótkich chromosomu 5, będzie związana z wystąpieniem u dziecka zespołu Cri du chat („zespół kociego krzyku”). Stwierdzona u płodu delecja obejmowała duży fragment krótkiego ramienia chromosomu 5, co zazwyczaj wiąże się ciężkim przebiegiem klinicznym zespołu u dziecka oraz niepełnosprawnością intelektualną. Dodatkowym obciążeniem, o trudnych do przewidzenia konsekwencjach klinicznych, była utrata krótkiego ramienia oraz niewielkiej części długiego ramienia chromosomu 21. W piśmiennictwie opisano zarówno zdrowych pacjentów z taką samą delecją (dotyczącą tylko chromosomu 21 bez utraty ramion krótkich chromosomu 5), jak i dzieci, u których wystąpiły mnogie wady wrodzone. Do pełnej oceny genetycznej zaplanowano dodatkowe badanie kariotypu rodziców, także w celu oceny ryzyka powtórzenia się aberracji chromosomowej u kolejnego dziecka.

Następnie pacjentkę konsultowano w ośrodku kardiologii prenatalnej, gdzie potwierdzono złożoną wadę serca - skrajną postać TOF z dekstropozycją aorty wynoszącą 50-70\%, z pniem płucnym położonym od tyłu do aorty (przełożenie wielkich pni tętniczych).

Ze względu na wielowadzie, nieprawidłowy kariotyp oraz ciężką wadę serca ostatecznie określono rokowanie jako niepomyślne, w związku z czym należało rozważyć objęcie noworodka oraz rodziny perinatalną opieką paliatywną. Rodziców dokładnie poinformowano o charakterze schorzenia i konieczności precyzyjnego zaplanowania postępowania okołoporodowego, z porodem drogami natury.

Pacjentka zgłosiła się ponownie w 38. tc. z powodu odpływania czystego płynu owodniowego i rozpoczynającej się czynności skurczowej mięśnia macicy. Poród odbył się drogami i siłami natury, bez powikłań. Noworodek płci żeńskiej, z masą urodzeniową 1700 g, urodził się w średnim stanie ogólnym (5 pkt. w skali Apgar w 1. min.). Po odśluzowaniu noworodka w laryngoskopie wentylowano workiem Ambu, po czym ułożono w inkubatorze i podłączono oddech zastępczy, który prowadzono przez 1 godzinę. Dziecko rozintubowano bez powikłań i pozostawiono na własnym oddechu; na stałe stosowano tlenoterapię. W trakcie hospitalizacji rozpoznano infekcje wrodzoną oraz niedokrwistość, z powodu której przetoczono dziecku koncentrat krwinek czerwonych. W badaniu USG mózgowia stwierdzono agenezję ciała modzelowatego ze znacznym poszerzeniem komór bocznych, a w badaniu echokardiograficznym potwierdzono skrajną postać TOF z zachowanym przepływem płucnym.

\section{Dyskwalifikacja \\ z leczenia kardiochirurgicznego}

Po 2 tygodniach dziecko przekazano na oddział pediatrii, gdzie dodatkowo stwierdzono niedoczynność tarczycy, po czym noworodka przekazano do szpitala znajdującego się bliżej miejsca zamieszkania rodziców. W trakcie dalszej hospitalizacji wykonano liczne badania laboratoryjne, a następnie przekazano niemowlę pod opiekę hospicjum. Dziewczynka była kilkakrotnie hospitalizowana z powodu ostrej niewydolności oddechowej w przebiegu zachłystu, a następnie diagnozowana na oddziale kardiologicznym z powodu małopłytkowości. Małopłytkowość u dziecka ze złożoną morfologią wrodzonej wady serca była podstawą czasowej dyskwalifikacji z zabiegu kardiochirurgicznego - zaplanowanej wstępnie paliatywnej operacji zespolenia systemowo-płucnego. Po sprecyzowaniu rozpoznania małopłytkowości autoimmunologicznej dziecko poddano 5-dniowej immunoterapii (globulina Intratect ${ }^{\circledR}$ firmy Sandoz); w 6. dobie leczenia uzyskano maksymalną zawartość płytek krwi, tj. 44 tys./ $\mathrm{mm}^{3}$, z jego spadkiem w kolejnych oznaczeniach.

Uzyskana liczba płytek krwi wystarczała do utrzymania prawidłowej hemostazy u dziecka leczonego zachowawczo i przewlekłej małopłytkowości, nie zapewniała jednak warunków bezpieczeństwa operacji kardiochirurgicznej, leczenia hybrydowego ani interwencji kardiologicznej. Z tego względu u dziewczynki zaplanowano kolejną immunoterapię lub leczenie metodą stymulacji steroidowej (pulsy metyloprednizolonu). Ostatecznie, ze względu na złożoną wrodzoną wade serca wymagającą wieloetapowego leczenia, ciężką postać zespołu genetycznego potwierdzonego w badaniach cytogenetycznych, ciężki przebieg kliniczny oraz liczne przeciwwskazania związane z dysfunkcją innych narządów towarzyszących złożonej wadzie serca, dziecka nie zakwalifikowano do leczenia kardiochirurgicznego.

\section{Dyskusja}

Diagnostyka prenatalna umożliwia rozpoznawanie anomalii płodowych we wczesnym okresie ciąży. Dzięki rozwojowi metod badawczych i technik obrazowania możliwe jest wykrywanie wad genetycznych i anomalii strukturalnych poszczególnych narządów, w tym wad układu sercowo-naczyniowego. Dzięki badaniom prenatalnym można przewidywać potencjalne problemy zdrowotne i inne skutki nieprawidłowego fenotypu u noworodka, wraz z przygotowaniem logistyki opieki nad pacjentką w ciąży, bezpiecznego porodu i strategii dalszego leczenia dziecka. Postępowanie takie nabiera szczególnego znaczenia w obliczu rozwoju terapii płodowej i postępów intensywnego leczenia noworodkowych stanów zagrożenia życia $[5,6]$. 
U opisanej ciężarnej rozpoznania zespołu Cri du chat u płodu dokonano prenatalnie na podstawie badań cytogenetycznych. Wskazaniem do pobrania krwi pępowinowej na badanie kariotypu płodu było współwystępowanie u płodu hipotrofii ze złożoną wadą serca i wentrikulomegalią. W piśmiennictwie podaje się, że zespołowi Cri du chat wady serca towarzyszą w około 30\% przypadków, najczęściej w postaci VSD, PDA oraz TOF [7]. W badaniu, które objęło 21 chorych z zespołem Cri du chat, u 6 stwierdzono VSD, u 6 - PDA, a u 5 pacjentów - TOF [7]. Wentrikulomegalia nie jest wprawdzie patognomonicznym objawem zespołu Cri du chat, ale związek ten już opisywano w piśmiennictwie [8]. Należy podkreślić, że właśnie ten objaw zainicjował dalszą diagnostykę oraz rozpoznanie złożonej wady serca.

Po urodzeniu dziecka potwierdzono u niego charakterystyczne dla zespołu cechy fenotypowe noworodka, typowe dla zespołu Cri du chat (tab. 1).

Ze względu na młody wiek dziewczynki nie można było ocenić charakterystycznych dla tego zespołu zaburzeń zachowania, takich jak: nadpobudliwość, stereotypie rucho-

Tabela 1. Objawy zespołu Cri du chat u opisanej dziewczynki (na podstawie [2])

$\begin{array}{lc}\text { Cechy zespołu wg [2] } & \begin{array}{c}\text { Obecność } \\ \text { objawów } \\ \text { u badanej }\end{array} \\ \text { Niska masa urodzeniowa <2500 g } & + \\ \text { Upośledzenie rozwoju fizycznego } & + \\ \text { Płacz „miauczenie kota” } & + \\ \text { Opóźnienie rozwoju psychoruchowego } & + \\ \text { Hipotonia } & + \\ \text { Małogłowie } & + \\ \text { Owalna twarz } & + \\ \text { Hiperteloryzm } & + \\ \text { Zmarszczka nakątna } & + \\ \text { Zez } & + \\ \text { Nisko osadzone małżowiny uszne } & + \\ \text { Wada serca } & + \\ \text { Inne cechy: rozszczepienie podniebienia, } & + \\ \text { wady zgryzu, dysplazja stawów biodrowych } & \end{array}$

we, agresja w stosunku do otoczenia, tendencja do samouszkodzeń czy zachowań autystycznych. W przeciwieństwie do starszych doniesień współczesne obserwacje wskazują na to, że dzieci z zespołem Cri du chat nie umierają we wczesnym okresie niemowlęcym [9]. Mimo występowania pewnych objawów przedwczesnego starzenia się większość chorych dożywa wieku dorosłego [1-4]. Rozpoznanie tego zespołu w czasie, kiedy płód nie jest jeszcze zdolny do życia poza organizmem matki, może być powodem medycznej terminacji ciąży. U opisywanej pacjentki zespół genetyczny wykryto zbyt późno, gdyż dopiero w 34. tc. W wykonanych badaniach kontrolnych została przeoczona ciężka wada serca jak też nie dość uważnie potraktowana pogłębiająca się hipotrofia.

Trwają badania nad związkiem wartości ludzkiej gonadotropiny kosmówkowej beta (ß-hCG, human chorion gonadotropin beta) a występowaniem zespołu Cri du chat, ale korelacja ta nie jest jeszcze do końca jasna [10]. W trakcie diagnostyki prezentowanej ciężarnej nie posługiwano się oznaczeniem ß-hCG jako patognomonicznym objawem zespołu genetycznego.

Ze względu na występowanie złożonej morfologii wrodzonej wady serca, z potencjalną koniecznością wieloetapowego leczenia, ciężką postać zespołu genetycznego potwierdzonego w szczegółowych badaniach cytogenetycznych, dotychczasowy ciężki przebieg kliniczny oraz liczne przeciwwskazania związane z dysfunkcją innych narządów towarzyszących złożonej wadzie serca dziecka ostatecznie nie zakwalifikowano do leczenia kardiochirurgicznego. Posiadanie wiedzy opartej na diagnostyce prenatalnej pozwala wstępnie przewidzieć ciężkie konsekwencje u noworodka oraz objąć kompleksową opieką paliatywną dziecko i jego rodzinę [11].

\section{Wnioski}

1. Dokładnie przeprowadzona diagnostyka prenatalna pozwala przewidzieć możliwe powikłania okresu noworodkowego, zaplanować miejsce i sposób porodu oraz ocenić możliwości leczenia kardiochirurgicznego dziecka obarczonego ryzykowną aberracją chromosomową. 2. Szczegółowe poradnictwo genetyczne umożliwia przygotowanie rodziców na urodzenie dziecka z wadą genetyczną i złożoną wrodzoną wadą serca, niekwalifikującą się do leczenia kardiochirurgicznego. 


\section{Abstract}

It was presented a case of prenatally diagnosed Cri du chat syndrome, complicated by multiple congenital heart disease, with many additional problems that eventually may become the basis for disqualification the child from complex cardiac surgery. Due to the complexity of congenital heart disease, the potential for multistage treatment, the severe form of the genetic syndrome confirmed by detailed cytogenetic studies, severe clinical course, and multiple organ dysfunction, patient has not been qualified for cardiac surgery.

Knowledge based on prenatal diagnosis allows to predict severe consequences in the newborn.

Detailed genetic counseling makes it possible to prepare parents for a genetic birth defect and a congenital heart defect not eligible for cardiac surgery.

Key words: prenatal diagnosis, fetal echocardiography, Cri du chat syndrome, congenital heart defects, perinatal care

Folia Cardiologica 2017; 12, 5: 523-527

\section{Piśmiennictwo}

1. Friedman JM, Dill IJ, Hayden MR. Aberracje chromosomowe. In: Limon J. ed. Genetyka. Urban and Partner, Wrocław 1997: 44.

2. Smith DW. Chromosomal abnormality syndromes. In: Smith DW. ed. Recognizable patterns of human malformation. Saunders Company, Philadelphia 1982: 38.

3. Feingold M. Chromosomal syndromes. In: Feingold M. ed. Genetics and birth defects in clinical practise. Little, Brown and Company, Boston-Toronto 1983: 222.

4. Wilkins LE, Brown JA, Wolf B. Psychomotor development in 65 homereared children with cri-du-chat syndrome. J Pediatr. 1980; 97(3): 401-405, indexed in Pubmed: 7411302.

5. Leszczyńska K, Chojnicki M, Haponiuk I, et al. [Analysis of pregnancy, labor and neonatal course in babies with prenatally-diagnosed complete atrioventricular heart block]. Ginekol Pol. 2015; 86(5): 366-371, doi: 10.17772/gp/2424, indexed in Pubmed: 26117975.

6. Haponiuk I, Chojnicki M, Szofer-Sendrowska A, et al. "Planned” permanent pacemaker implantation in one-day-old newborn after prenatal diagnosis of congenital complete atrioventricular heart block. Kardiochir Torakochirurgia Pol. 2014; 11(1): 76-78, doi: 10.5114/ kitp.2014.41937, indexed in Pubmed: 26336400.
7. Hills C, Moller JH, Finkelstein M, et al. Cri du chat syndrome and congenital heart disease: a review of previously reported cases and presentation of an additional 21 cases from the Pediatric Cardiac Care Consortium. Pediatrics. 2006; 117(5): e924-e927, doi: 10.1542/ peds.2005-1012, indexed in Pubmed: 16585274.

8. Stefanou EGG, Hanna G, Foakes A, et al. Prenatal diagnosis of cri du chat (5p-) syndrome in association with isolated moderate bilateral ventriculomegaly. Prenat Diagn. 2002; 22(1): 64-66, doi: 10.1002/ pd.243, indexed in Pubmed: 11810654.

9. Diop IB, Sy Signate H, Ba SA, et al. [Cri-du-chat syndrome. A case report]. Dakar Med. 2000; 45(1): 95-97, indexed in Pubmed: 14666800.

10. Weiss A, Shalev S, Weiner E, et al. Prenatal diagnosis of $5 p$ deletion syndrome following abnormally low maternal serum human chorionic gonadotrophin. Prenat Diagn. 2003; 23(7): 572-574, doi: 10.1002/ pd.645, indexed in Pubmed: 12868086.

11. Freud LR, Escobar-Diaz MC, Kalish BT, et al. Outcomes and predictors of perinatal mortality in fetuses with ebstein anomaly or tricuspid valve dysplasia in the current era: a multicenter study. Circulation. 2015; 132(6): 481-489, doi: 10.1161/CIRCULATIONAHA.115.015839, indexed in Pubmed: 26059011. 